\title{
Optimalisasi Sistem Pendukung Keputusan Pemilihan Toko Daring Terbaik Menggunakan Metode ANP(Studi Kasus Politeknik Ganesha)
}

\author{
Romindo $^{1}$, Jamaludin ${ }^{2}$ \\ Politeknik Ganesha \\ Jl. Veteran No.190 Pasar VI Manunggal, Medan, Indonesia, (061) 80027492 \\ 1romindo4@gmail.com, 2jamaludinmedan@gmail.com
}

\begin{abstract}
Thick store business activities are growing, online purchases and sales are growing. The community does not need to leave home and face congestion if they want to buy goods. The development in the special society of the Polytechnic students of Ganesha is the purchase of using the internet, which is known as an online store. Polytechnic students from Ganesha often discuss online shops. Talk about thick stores to meet student needs in online purchases, and choose which thick store is best for online shopping. With this explanation, it is important to consider which decision to choose the best thick store in the Ganesha Polytechnic environment using the Analytic Network Process (ANP) method. In this method, 10 criteria will be processed, namely: Online Phone / Chat Numbers, Popular Products, Free Shipping, Shipping Systems, Logos, Social Media Links, Search Stores, Product Brands, Latest News, and Trusmark and 3 types of alternatives Online. Stores, namely: Bukalapak, Shopee and Lazada. The results of research on data processing using the ANP method indicate the type of Online Store that can be recommended for students of Ganesha Polytechnic as consumers who buy online from the highest to lowest order are Lazada $=0.114$, Shopee $=$ 3.80, Bukalapak $=3.73$ and Lazada $=2.47$.
\end{abstract}

Keywords: Online Store, Decision Support System, ANP

\begin{abstract}
Abstrak-Aktivitas bisnis toko daring semakin berkembang pesat, jual-beli online pun semakin marak dilakukan. Masyarakat tidak perlu keluar rumah dan menghadapai macetnya jalan jika ingin membeli suatu barang. Perkembangan di masyarakat khususnya mahasiswa Politeknik Ganesha adalah berbelanja menggunakan internet atau dikenal dengan online shop. Mahasiswa Politeknik Ganesha sering kali memperbincangkan toko daring. Perbincangan seputar toko daring untuk memenuhi kebutuhan mahasiswa dalam berbelanja online, serta memilih toko daring mana yang terbaik dalam berlanja Online. Dengan penjelasan tersebut maka penting diketahui dalam menentukan keputusan pemilihan toko daring mana yang terbaik dilingkungan Politeknik Ganesha dengan menggunakan metode Analytic Network Process (ANP). Pada metode ini 10 kriteria yang akan diolah yaitu: Nomor Telepon/Chatting Online, Produk Popular, Gratis Ongkos Kirim, Sistem Pemabayaran, Logo, Sosial Media Link, Toko Finder, Merk Produk, Berita Terbaru, dan Trusmark dan 3 alternatif jenis Toko Daring yaitu: Bukalapak, Shopee dan Lazada. Hasil penelitian pada pengolahan data menggunakan metode ANP menunjukkan bahwa jenis toko daring yang bisa direkomendasikan untuk mahasiswa Politeknik Ganesha sebagai konsumen jul beli online dari urutan tertinggi sampai dengan terendah adalah Lazada $=0,114$, Shopee $=3.80$, Bukalapak $=3.73$, dan Lazada $=2.47$.
\end{abstract}

Kata kunci: Toko Daring, Sistem Pendukung Keputusan, ANP 


\section{PENDAHULUAN}

Dewasa ini perkembangan teknologi informasi sudah sedemikian pesat. Perkembangan yang pesat tidak hanya teknologi perangkat keras dan perangkat lunak saja, tetapi metode komputasi juga ikut berkembang. Salah satu metode komputasi yang cukup berkembang saat ini adalah metode sistem pengambilan keputusan (Decisions Support System). Dalam teknologi informasi, sistem pengambilan keputusan merupakan cabang ilmu yang letaknya diantara system informasi dan sistem cerdas. Toko daring merupakan proses penjualan/pembelian, atau pertukaran barang atau jasa dengan menggunakan jaringan komputer. Toko daring bagi sebagian perusahaan saat ini merupakan bagian dari nilai keunggulan dalam persaingan competitive advantage saat ini. Toko daring digunakan perusahaan dalam pegembangan pemasaran, pengiriman, pelayanan, dan pembayaran pelanggan. Perkembangan toko daring dilndonesia sendiri telah ada sejak tahun 1996 hingga saat ini toko daring yang cukup populer saat ini di Indonesia diantaranya Lazada, Shopee, blibli, tokopedia, bukalapak dan lain-lain. Hasil penelitian yang dilakukan oleh Kompas 5 Oktober 2012, menunjukkan bahwa pada tahun 2012 sebanyak 53,2\% responden yang berbelanja secara online adalah mereka yang pengeluarannya lebih dari Rp 2.000.000,00 per bulan. Ratarata pekerjaan mereka adalah karyawan swasta (sebanyak 33,9\%) dan wiraswasta (sebanyak 19,4\%). Selain itu, para pelajar dan mahasiswa juga memiliki minat untuk berbelanja online dengan angka 19,9\% (Kompasiana.com, 2012). Hari ini sedang berkembang di masyarakat khususnya mahasiswa Politeknik Ganesha adalah berbelanja menggunakan internet atau dikenal dengan online shop. Mahasiswa Politeknik Ganesha sering kali memperbincangkan toko daring. Perbincangan seputar toko daring untuk memenuhi kebutuhan mahasiswa dalam berbelanja online, serta memilih toko daring mana yang terbaik dalam berlanja Online. Hal ini yang memberikan keingintahuan peneliti lebih mendalam mengenai penentuan toko daring mana yang terbaik dalam berbelanja online, melihat banyaknya toko daring yang beredar saat ini.

Metode yang digunakan oleh peneliti dalam menentukan keputusan adalah Metode analytic network process. Dimana Analytic Network Process (ANP) merupakan metode yang menghasilkan kerangka kerja untuk mengatasi permasalahan pengambil keputusan tanpa membuat asumsi yang berkaitan dengan independensi antara level elemen yang lebih tinggi dengan lemah dan independensi dari elemen-elemen dalam satu level. ANP menggunakan network tanpa penjelasan yang spesifik tentang level-level yang ada seperti pada suatu hirarki. Aktivitas saling mempengaruhi merupakan konsep inti dari ANP. Dengan penjelasan tersebut maka sangat penting diketahui dalam menentukan keputusan pemilihan toko daring mana yang terbaik dilingkungan Politeknik Ganesha dengan menggunakan metode Analytic Network Process (ANP) dengan beberapa kriteria dan alternatif.

\section{METODOLOGI PENELITIAN}

Pemilihan Toko Daring Terbaik dengan Metode ANP (Romindo) | 8 
Beberapa penelitian yang menjadi referensi penelitian ini adalah :

a. Penelitian yang dilakukan oleh Fifin Sonata dengan judul "analisis studi kelayakan pelayanan e-commerce menggunakan metode analytical hierarchy process ( $a h p$ )". Jurnal Komunikasi, Media dan Informatika, Vol. 7 No. 2 /Agustus 2018. Penelitian ini membahas tentang penerapan metode AHP pada sistem pendukung keputusan yang digunakan untuk mengolah dan menganalisa jenis e-commerce yang layak direkomendasikan untuk konsumen di Indonesia.

b. Penelitian yang dilakukan oleh Kristophorus Kanaprio Ola dan Tri Joko Wahyu Adi, dengan judul "pemilihan kontraktor di proyek konstruksi pt. $x$ dengan metode analytic network process". Prosiding Seminar Nasional Manajemen Teknologi XX Program Studi MMT-ITS, Surabaya 1 Februari 2014. Penelitian ini membahas tentang Model pemilihan kontraktor yang sesuai dengan tujuan dan kebutuhan perusahaan terdiri dari 5 kriteria, yaitu kemampuan teknis, kemampuan organisasi, keselamatan dan kesehatan kerja, kemampuan internal dan harga penawaran.

c. Penelitian oleh Shanti Indri Hapsari dan Ahmad Rusdianyah, dengan judul "aplikasi sistem pendukung keputusan berbasis spreadsheet untuk menganalisis biaya penyelenggaraan pendidikan di program mmt-its". Prosiding Seminar Nasional Manajemen Teknologi VIII Program Studi MMT-ITS, Surabaya 2 Agustus 2008. Penelitian ini membahas tentanag simulasi proyeksi anggaran yang menghasilkan informasi keuangan berupa perhitungan biaya studi per mahasiswa. Proyeksi juga dapat digunakan untuk menghasilkan beberapa alternatif model proyeksi anggaran operasional pendidikan untuk beberapa tahun sehingga manajemen dapat memilih model anggaran yang menghasilkan komposisi anggaran penerimaan dan pengeluaran yang optimal sesuai sasaran yang akan dicapai oleh pihak manajemen.

d. Penelitian yang dilakukan oleh Melwin Syafrizal, dengan judul "sistem pendukung keputusan (decision support system)". Jurnal DASI ISSN: 1411-3201 Vol. 11 no. 3 september 2010. Penelitian ini membahas tentang bagaimana sistem pendukung keputusan (DSS) dibuat sebagai suatu cara untuk memenuhi kebutuhan seorang manajer dalam membuat keputusan yang spesifik dalam memecahkan permasalah yang spesifik pula. EIS Merupakan program pemberi nasihat atau program konsultasi yang berisi pengetahuan dan pengalaman yang dimasukkan oleh satu atau banyak pakar untuk dapat dimanfaatkan dalam memecahkan berbagai masalah.

e. Penelitian dilakukan oleh Yuli Astuti, M. Suyanto, Kusrini, dengan judul "sistem pendukung keputusan untuk pemilihan perguruan tinggi komputer swasta". Jurnal DASI ISSN: 1411-3201 vol. 12 no. 1 maret 2011. Penelitian ini membahas tentang sistem pendukung keputusan untuk memilih perguruan tinggi komputer swasta akan dilakukan menggunakan metode AHP dengan kriteria fasilitas,biaya dan kualitas.

f. Penelitian dilakukan oleh Zulfa Fitri Ikatrinasari, Syamsul Maarif, Endang Gumbira Sa'id, Tajuddin Bantacut, Aris Munandar, dengan judul "model pemilihan kelembagaan agropolitan berbasis agroindustri dengan analytical network process". J. Tek. Ind. Pert. Vol. 19(3), 130-137. Penelitian ini membahas tentang model pemilihan kelembagaan agropolitan berbasis agroindustri 
menggunakan metoda ANP yang bersifat kompleks dan terdiri dari komponenkomponen kriteria dan alternatif yang memiliki beragam variasi interaksi.

g. Penelitian dilakukan oleh Iwan Vanany, dengan judul "aplikasi analytic network process (anp) pada perancangan sistem pengukuran kinerja (studi kasus pada pt. $x$ )". Jurnal teknik industri vol. 5, no. 1, juni 2003: 50 - 62. Penelitian tersebut adalah membahas aplikasi Analytic Network Process (ANP) untuk mendukung pembobotan pada perancangan sistem pengukuran kinerja dengan metode Balanced Scorecard.

h. Oleh Chandra Priyandika dan Mosses L. Singgih, dengan judul "pengambilan keputusan multi kriteriadalam pemilihan vendor alat pelindung diri (apd) dengan pendekatan risk management dan analysis network process (anp)". Prosiding Seminar Nasional Manajemen Teknologi XIII Program Studi MMT-ITS, Surabaya 5 Pebruari 2011. Penelitian tersebut adalah menerapkan metode Risk Management untuk menentukan resiko dari setiap hazard yang ada pada workshop, sehingga kebutuhan APD dapat diidentifikasi dengan baik. Hasil dari identifikasi kebutuhan APD akan dijadikan alat untuk memilih prioritas vendor yang akan dipilih. Pemilihan vendor ini menggunakan metode Analytical Network Process (ANP).

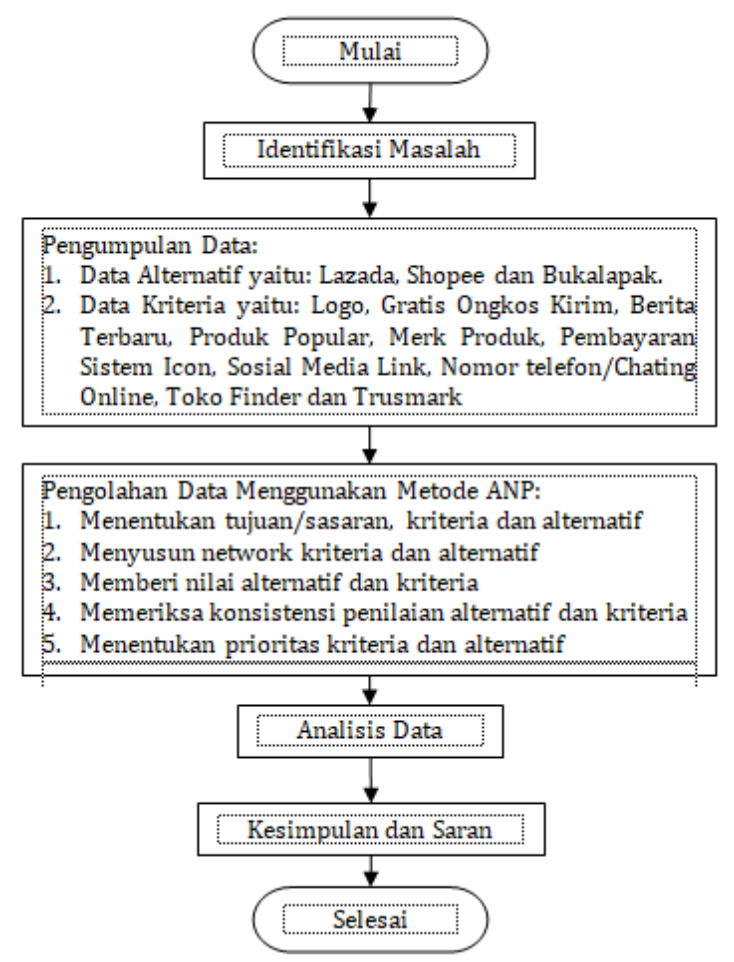

Gambar 1. Flowchart Penelitian

\section{HASIL DAN PEMBAHASAN \\ 2.1 Penentuan Kriteria dan Sub Kriteria}

Pemilihan Toko Daring Terbaik dengan Metode ANP (Romindo) | 10 
Terdapat 10 kriteria, dan 3 alternatif yang digunakan pada penentuan toko daring terbaik dan dapat dilihat pada Tabel 1 dan Tabel 2. Berdasarkan identifikasi keterkaitan antar kriteria dapat diketahui bahwa dalam menentukan toko daring terbaik menggunakan kriteria yang saling terkait. Oleh karena itu, maka metode yang tepat digunakan untuk menentukan toko daring terbaik adalah metode ANP.

Tabel 1. Kriteria

\begin{tabular}{|l|l|}
\hline \multirow{4}{*}{ Kriteria } & Nomor telefon/Chating Online (NT) \\
\cline { 2 - 3 } & Produk Popular (PP) \\
\cline { 2 - 3 } & Gratis Ongkos Kirim (GOK) \\
\cline { 2 - 3 } & Sistem Pembayaran (SP) \\
\cline { 2 - 3 } & Logo (L) \\
\cline { 2 - 3 } & Sosial Media Link (SML) \\
\cline { 2 - 3 } & Toko Finder (TF) \\
\cline { 2 - 3 } & Merk Produk (MP) \\
\cline { 2 - 3 } & Berita Terbaru (BT) \\
\cline { 2 - 3 } & Trusmark (T) \\
\hline
\end{tabular}

Tabel 2. Alternatif

\begin{tabular}{|l|l|}
\hline Alternatif & Lazada \\
\cline { 2 - 2 } & Shopee \\
\cline { 2 - 2 } & BukaLapak \\
\hline
\end{tabular}

\subsection{Analisis bobot kriteria}

Tabel 3. Perbandingan Berpasangan

\begin{tabular}{|c|c|c|c|c|c|c|c|c|c|c|}
\hline Kriteria & NT & PP & GOK & SP & L & SML & TF & MP & BT & T \\
\hline NT & 1 & 2 & $1 / 2$ & $1 / 2$ & 3 & 3 & 4 & 2 & 3 & 3 \\
\hline PP & $1 / 2$ & 1 & $1 / 3$ & $1 / 2$ & 3 & 3 & 3 & 2 & 2 & 2 \\
\hline GOK & 2 & 3 & 1 & 2 & 4 & 3 & 4 & 2 & 3 & 3 \\
\hline SP & 2 & 2 & $1 / 2$ & 1 & 3 & 2 & 3 & 2 & 2 & 2 \\
\hline L & $1 / 3$ & $1 / 3$ & $1 / 4$ & $1 / 3$ & 1 & $1 / 2$ & 2 & $1 / 2$ & $1 / 2$ & $1 / 3$ \\
\hline SML & $1 / 3$ & $1 / 3$ & $1 / 3$ & $1 / 2$ & 2 & 1 & 2 & $1 / 2$ & $1 / 2$ & $1 / 3$ \\
\hline TF & $1 / 4$ & $1 / 3$ & $1 / 4$ & $1 / 3$ & $1 / 2$ & $1 / 2$ & 1 & $1 / 3$ & $1 / 2$ & $1 / 2$ \\
\hline MP & $1 / 2$ & $1 / 2$ & $1 / 2$ & $1 / 2$ & 2 & 2 & 3 & 1 & 2 & 2 \\
\hline BT & $1 / 3$ & $1 / 2$ & $1 / 3$ & $1 / 2$ & 2 & 2 & 2 & $1 / 2$ & 1 & $1 / 4$ \\
\hline T & $1 / 3$ & $1 / 2$ & $1 / 3$ & $1 / 2$ & 3 & 3 & 2 & $1 / 2$ & 4 & 1 \\
\hline
\end{tabular}

Matriks diatas dievaluasi dan dijumlahkan setiap kolomnya sehingga didapatkan hasil seperti ditunjukkan pada Tabel 4 dibawah ini:

Tabel 4. Evaluasi Perbandingan Berpasangan

\begin{tabular}{|c|c|c|c|c|c|c|c|c|c|c|}
\hline Kriteria & NT & PP & GOK & SP & L & SML & TF & MP & BT & T \\
\hline NT & 1.00 & 2.00 & 0.50 & 0.50 & 3.00 & 3.00 & 4.00 & 2.00 & 3.00 & 3.00 \\
\hline PP & 0.50 & 1.00 & 0.33 & 0.50 & 3.00 & 3.00 & 3.00 & 2.00 & 2.00 & 2.00 \\
\hline GOK & 2.00 & 3.00 & 1.00 & 2.00 & 4.00 & 3.00 & 4.00 & 2.00 & 3.00 & 3.00 \\
\hline SP & 2.00 & 2.00 & 0.50 & 1.00 & 3.00 & 2.00 & 3.00 & 2.00 & 2.00 & 2.00 \\
\hline L & 0.33 & 0.33 & 0.25 & 0.33 & 1.00 & 0.50 & 2.00 & 0.50 & 0.50 & 0.33 \\
\hline SML & 0.33 & 0.33 & 0.33 & 0.50 & 2.00 & 1.00 & 2.00 & 0.50 & 0.50 & 0.33 \\
\hline TF & 0.25 & 0.33 & 0.25 & 0.33 & 0.50 & 0.50 & 1.00 & 0.33 & 0.50 & 0.50 \\
\hline MP & 0.50 & 0.50 & 0.50 & 0.50 & 2.00 & 2.00 & 3.00 & 1.00 & 2.00 & 2.00 \\
\hline BT & 0.33 & 0.50 & 0.33 & 0.50 & 2.00 & 2.00 & 2.00 & 0.50 & 1.00 & 0.25 \\
\hline
\end{tabular}




\begin{tabular}{|c|c|c|c|c|c|c|c|c|c|c|}
\hline Kriteria & NT & PP & GOK & SP & L & SML & TF & MP & BT & T \\
\hline T & 0.33 & 0.50 & 0.33 & 0.50 & 3.00 & 3.00 & 2.00 & 0.50 & 4.00 & 1.00 \\
\hline Jumlah & 7.57 & 10.49 & 4.32 & 6.66 & 23.5 & 20 & 26 & 11.33 & 18.5 & 14.41 \\
\hline
\end{tabular}

Setelah jumlah kolomnya ditentukan, angka-angka dalam matriks $10 \times 10$ tersebut dibagi dengan jumlah kolomnya masing-masing sehingga menghasilkan matriks 10 x 10 hasil penjumlahan kolom berikut ini :

Tabel 5. Hasil Penjumlahan Kriteria

\begin{tabular}{|c|c|c|c|c|c|c|c|c|c|c|c|}
\hline Kriteria & NT & PP & GOK & SP & L & SML & TF & MP & BT & T & Jumlah \\
\hline NT & 0.13 & 0.19 & 0.12 & 0.08 & 0.13 & 0.15 & 0.15 & 0.18 & 0.16 & 0.21 & 1.49 \\
\hline PP & 0.07 & 0.10 & 0.08 & 0.08 & 0.13 & 0.15 & 0.12 & 0.18 & 0.11 & 0.14 & 1.13 \\
\hline GOK & 0.26 & 0.29 & 0.23 & 0.30 & 0.17 & 0.15 & 0.15 & 0.18 & 0.16 & 0.21 & 2.10 \\
\hline SP & 0.26 & 0.19 & 0.12 & 0.15 & 0.13 & 0.10 & 0.12 & 0.18 & 0.11 & 0.14 & 1.49 \\
\hline L & 0.04 & 0.03 & 0.06 & 0.05 & 0.04 & 0.03 & 0.08 & 0.04 & 0.03 & 0.02 & 0.42 \\
\hline SML & 0.04 & 0.03 & 0.08 & 0.08 & 0.09 & 0.05 & 0.08 & 0.04 & 0.03 & 0.02 & 0.53 \\
\hline TF & 0.03 & 0.03 & 0.06 & 0.05 & 0.02 & 0.03 & 0.04 & 0.03 & 0.03 & 0.03 & 0.35 \\
\hline MP & 0.07 & 0.05 & 0.12 & 0.08 & 0.09 & 0.10 & 0.12 & 0.09 & 0.11 & 0.14 & 0.94 \\
\hline BT & 0.04 & 0.05 & 0.08 & 0.08 & 0.09 & 0.10 & 0.08 & 0.04 & 0.05 & 0.02 & 0.62 \\
\hline T & 0.04 & 0.05 & 0.08 & 0.08 & 0.13 & 0.15 & 0.08 & 0.04 & 0.22 & 0.07 & 0.93 \\
\hline
\end{tabular}

Skala bobot prioritas, bisa didapat dengan cara menghitung rata-rata baris dari matriks 4 x 4 , hasilnya bisa dilihat berikut ini :

Tabel 6. Skala Pembobotan Perbandingan Berpasangan

\begin{tabular}{|c|c|c|c|c|c|c|c|c|c|c|c|}
\hline Kriteria & NT & $\mathbf{P P}$ & GOK & SP & $\mathbf{L}$ & SML & TF & MP & BT & $\mathbf{T}$ & $\begin{array}{c}\text { Priorit } \\
y \\
\text { Vector }\end{array}$ \\
\hline NT & 1.00 & 2.00 & 0.50 & 0.50 & 3.00 & 3.00 & 4.00 & 2.00 & 3.00 & 3.00 & 0.15 \\
\hline PP & 0.50 & 1.00 & 0.33 & 0.50 & 3.00 & 3.00 & 3.00 & 2.00 & 2.00 & 2.00 & 0.11 \\
\hline GOK & 2.00 & 3.00 & 1.00 & 2.00 & 4.00 & 3.00 & 4.00 & 2.00 & 3.00 & 3.00 & 0.21 \\
\hline SP & 2.00 & 2.00 & 0.50 & 1.00 & 3.00 & 2.00 & 3.00 & 2.00 & 2.00 & 2.00 & 0.15 \\
\hline $\mathrm{L}$ & 0.33 & 0.33 & 0.25 & 0.33 & 1.00 & 0.50 & 2.00 & 0.50 & 0.50 & 0.33 & 0.04 \\
\hline SML & 0.33 & 0.33 & 0.33 & 0.50 & 2.00 & 1.00 & 2.00 & 0.50 & 0.50 & 0.33 & 0.05 \\
\hline $\mathrm{TF}$ & 0.25 & 0.33 & 0.25 & 0.33 & 0.50 & 0.50 & 1.00 & 0.33 & 0.50 & 0.50 & 0.03 \\
\hline MP & 0.50 & 0.50 & 0.50 & 0.50 & 2.00 & 2.00 & 3.00 & 1.00 & 2.00 & 2.00 & 0.09 \\
\hline BT & 0.33 & 0.50 & 0.33 & 0.50 & 2.00 & 2.00 & 2.00 & 0.50 & 1.00 & 0.25 & 0.06 \\
\hline $\mathrm{T}$ & 0.33 & 0.50 & 0.33 & 0.50 & 3.00 & 3.00 & 2.00 & 0.50 & 4.00 & 1.00 & 0.09 \\
\hline \multicolumn{11}{|l|}{ Jumlah } & 1.00 \\
\hline \multicolumn{11}{|c|}{ Principal Eigen Value } & 10.72 \\
\hline \multicolumn{11}{|c|}{ Consistency Index } & 0.08 \\
\hline \multicolumn{11}{|c|}{ Consistency Rasio } & 0.54 \\
\hline
\end{tabular}

Dari Tabel 5 Dapat dijelaskan sebagai berikut:

1. Jumlah merupakan penjumlahan dari semua angka yang ada pada baris diatasnya dalam satu kolom.

2. Priority Vector merupakan hasil penjumlahan dari semua sel disebelah kirinya (pada baris yang sama) setelah terlebih dahulu dibagi dengan jumlah yang ada dibawahnya, kemudian hasil penjumlahan tersebut dibagi dengan angka.

3. Angka 10 diperoleh dari jumlah kriteria yaitu Nomor Telpon/Chatting Online (NT), Produk Popular (PP), Gratis Ongkos Kirim (GOK), Sistem Pembayaran 
(SP), Logo (L), Sosial Media Link (SML), Toko Finder (TF), Merk Produk (MP), Berita Terbaru (BT) dan Trusmark (T).

4. Priority vector Nomor Telpon/Chatting Online $(\mathrm{NT})=0.15$ diperoleh dari $((1 / 7.57)+(2 / 10.49)+(0.5 / 4.32)+(0.5 / 6.66)+(3 / 23.5)+(3 / 20)+(4 / 26)+$ $(2 / 11.33)+(3 / 18.5)+(3 / 14.41) * 1 / 10$

5. Priority Vector Produk Popular $(\mathrm{PP})=0.11$ diperoleh dari $((0.5 / 7.57)$ $+(1 / 10.49)+(0.33 / 4.32)+(0.5 / 6.66)+(3 / 23.5)+(3 / 20)+(3 / 26)+(2 / 11.33)$ $+(2 / 18.5)+(2 / 14.41) * 1 / 10$

6. Priority Vector Gratis Ongkos Kirim $(\mathrm{GOK})=0.21$ diperoleh dari $((2 / 7.57)$ $+(3 / 10.49)+(1 / 4.32)+(2 / 6.66)+(4 / 23.5)+(3 / 20)+(4 / 26)+(2 / 11.33)+$ $(3 / 18.5)+(3 / 14.41) * 1 / 10$

7. Priority Vector Sistem Pembayaran $(\mathrm{SP})=0.15$ diperoleh dari $((2 / 7.57)$ $+(2 / 10.49)+(0.5 / 4.32)+(1 / 6.66)+(3 / 23.5)+(2 / 20)+(3 / 26)+(2 / 11.33)+$ $(2 / 18.5)+(2 / 14.41) * 1 / 10$

8. Priority Vector Logo $(L)=0.04$ diperoleh dari $((0.33 / 7.57)+(0.33 / 10.49)+$ $\begin{aligned} & (0.25 / 4.32)+(0.33 / 6.66)+(1 / 23.5)+(0.5 / 20)+(2 / 26)+ \\ & (0.5 / 11.33)+(0.5 / 18.5)+(0.33 / 14.41) * 1 / 10\end{aligned}+$

9. Priority Vector Sosial Media Link $(S M L)=0.05$ diperoleh dari $((0.33 / 7.57)$ $+(0.33 / 10.49)+(0.33 / 4.32)+(0.5 / 6.66)+(2 / 23.5)+(1 / 20)+(2 / 26)+$ $(0.5 / 11.33)+(0.5 / 18.5)+(0.33 / 14.41) * 1 / 10$

10. Priority Vector Toko Finder $(\mathrm{TF})=0.03$ diperoleh dari $((0.25 / 7.57)$ $+(0.33 / 10.49)+(0.25 / 4.32)+(0.33 / 6.66)+(0.5 / 23.5)+(0.5 / 20)+(1 / 26)+$ $(0.33 / 11.33)+(0.5 / 18.5)+(0.5 / 14.41) * 1 / 10$

11. Priority Vector Merk Produk (MP) $=0.09$ diperoleh dari ( $(0.5 / 7.57)$ $+(0.5 / 10.49)+(0.5 / 4.32)+(0.5 / 6.66)+(2 / 23.5)+(2 / 20)+(3 / 26)+$ $(1 / 11.33)+(2 / 18.5)+(2 / 14.41) * 1 / 10$

12. Priority Vector Berita Terbaru $(\mathrm{BT})=0.06$ diperoleh dari $((0.33 / 7.57)$ $+(0.5 / 10.49)+(0.33 / 4.32)+(0.5 / 6.66)+(2 / 23.5)+(2 / 20)+(2 / 26)+$ $(0.5 / 11.33)+(1 / 18.5)+(0.25 / 14.41) * 1 / 10$

13. Priority Vector Trusmark $(T)=0.09$ diperoleh dari $((0.33 / 7.57)+(0.5 / 10.49)+$
$(0.3 / 4.32)$
$(0.5 / 6.66)+(3 / 23.5)$
$+(3 / 20)+$
$(2 / 26)$
$(0.5 / 11.33)+(4 / 18.5)+(1 / 14.41) * 1 / 10$

14. Prioity Vector menunjukan bobot dari masing-masing kriteria, jadi dalam hal ini Gratis Ongkos Kirim (GOK) merupakan bobot tertinggi/terpenting dalam kriteria memilih toko daring terbaik, disusul Nomor Telepon dan Sistem Pembayaran, hingga yang terakhir adalah Toko Finder.

15. Setelah mendapatkan bobot untuk setiap kriteria (yang ada pada kolom Priority Vector), maka selanjutnya mengecek apakah bobot yang dibuat konsisten atau tidak. Untuk hal ini, yang pertama dilakukan adalah menghitung Principal EigenValue (max) matrix.

16. Principal EigenValue (max) matrix perhitungannya dengan cara menjumlahkan hasil perkalian antara jumlah dan priority vector.

17. Principal Eigen Value $(\max ) \rightarrow(7.57 \times 0.15)+(10.49 \times 0.11)+(4.32 \times 0.21)+$ $(6.66 \times 0.15)+(23.5 \times 0.04)+(20 \times 0.05)+(26 \times 0.03)+(11.33 \times 0.09)+$ $(18.5 \times 0.06)+(14.41 \times 0.09)=10.72$ 
18. Menghitung Consistency Index (CI) dengan rumus $\mathrm{CI}=(\max -\mathrm{n}) /(\mathrm{n}-1)$, untuk $\mathrm{n}=$ $10, \mathrm{CI}=(10.72-10) /(10-1)=0.08$. CI sama dengan nol koma nol satu tiga berarti pembobotan yang dilakukan sangat konsisten

19. Menghitung Consistency Ratio (CR) diperoleh dengan rumus $\mathrm{CR}=\mathrm{CI} / \mathrm{RI}$, nilai RI bergantung pada jumlah kriteria seperti pada tabel 6 berikut:

Tabel 7. Nilai Indeks Random Dari Kriteria

\begin{tabular}{|c|c|}
\hline Ukuran Matriks & Nilai RI \\
\hline 1.2 & 0.00 \\
\hline 3 & 0.58 \\
\hline 4 & 0.90 \\
\hline 5 & 1.12 \\
\hline 6 & 1.24 \\
\hline 7 & 1.32 \\
\hline 8 & 1.41 \\
\hline 9 & 1.45 \\
\hline 10 & 1.49 \\
\hline 11 & 1.51 \\
\hline 12 & 1.48 \\
\hline 13 & 1.56 \\
\hline 14 & 1.57 \\
\hline 15 & 1.59 \\
\hline
\end{tabular}

Jadi untuk $\mathrm{n}=10$, maka $\mathrm{RI}=1.49$

$\mathrm{CR}=\mathrm{CI} / \mathrm{RI}=0.08 / 1.49=0.54$

Jika hasil perhitungan CR lebih kecil atau sama dengan 10\% (0.1), ketidak konsistenan masih bias diterima, sebaliknya jika lebih besar dari10\%, tidak bisa diterima.

\begin{tabular}{|c|c|c|}
\hline+ & 3. Results & \\
\hline Normal -1 & & Hybrid -1 \\
\hline \multicolumn{3}{|c|}{ Inconsistency: 0.04754} \\
\hline Berita Te & & 0.05978 \\
\hline Gratis On & & 0.21195 \\
\hline Logo & & 0.04084 \\
\hline Merk Prod & & 0.09385 \\
\hline Nomor Tel & & 0.15192 \\
\hline Produk Po & & 0.11332 \\
\hline Sistem $\mathrm{Pe} \sim$ & & 0.15101 \\
\hline Sosial Me & & 0.05111 \\
\hline Toko Find & & 0.03446 \\
\hline Trustmark & & 0.09175 \\
\hline
\end{tabular}

Gambar 2. Bobot Prioritas pada kriteria

Perhitungan metode ANP pada tabel 5 dan gambar 2 menjelaskan bahwa kriteria Gratis Ongkos Kirim (GOK) dengan bobot 0.21 sebagai prioritas utama, diikuti oleh Sistem Pembayaran (SP) dengan bobot 0.15, kemudian Nomor Telepon/Chating Online (NT), Produk Popular (PP), Merk Produk (MP), Trusmark (T), Berita Terbaru (BT), Sosial Media Link (SML), Logo (L) dan yang terakhir Toko Finder (TF). Dengan perhitungan metode ANP bobot alternatif dapat ditentukan. Tabel 7 adalah hasil perhitungan metode ANP pada alternatif. 


\subsection{Bobot Prioritas}

Tabel 8. Bobot Prioritas Global Tingkat Alternatif (ANP)

\begin{tabular}{|l|c|c|c|c|}
\hline Kriteria & Bobot & Buka Lapak & Shopee & Lazada \\
\hline Nomor telepon/Chating Online & 0.15 & 0.37 & 0.38 & 0.25 \\
\hline Produk Popular & 0.11 & 0.37 & 0.40 & 0.23 \\
\hline Gratis Ongkos Kirim & 0.21 & 0.37 & 0.38 & 0.25 \\
\hline Sistem Pembayaran & 0.15 & 0.39 & 0.36 & 0.26 \\
\hline Logo & 0.04 & 0.37 & 0.39 & 0.24 \\
\hline Sosial Media Link & 0.05 & 0.38 & 0.37 & 0.24 \\
\hline Toko Finder & 0.03 & 0.37 & 0.38 & 0.25 \\
\hline Merk Produk & 0.09 & 0.36 & 0.38 & 0.27 \\
\hline Berita Terbaru & 0.06 & 0.38 & 0.39 & 0.23 \\
\hline Trusmark & 0.09 & 0.37 & 0.38 & 0.25 \\
\hline Bobot Prioritas & 1.00 & 3.73 & 3.80 & 2.47 \\
\hline
\end{tabular}

Berdasarkan hasil pengolahan data di atas masing-masing bobot kriteria hal ini mengandung arti bahwa kriteria gratis ongkos kirim merupakan kriteria yang terpenting diantara kriteria yang lain. Sedangkan hasil evaluasi alternatif yang memiliki bobot prioritas yang paling tinggi adalah alternatif Shopee. Oleh karena itu Shopee dipilih sebagai toko terbaik di lingkungan mahasiswa Politeknik Ganesha Medan. Shopee memiliki bobot prioritas sebesar 3.80, Buka Lapak sebesar 3.73, Lazada sebesar 2.47.

\section{KESIMPULAN}

a. Kesimpulan dari hasil penelitian ini adalah sebagai berikut:

Model pengambilan keputusan yang digunakan adalah Analytic Network Process (ANP). Model ini digunakan karena sesuai dengan kondisi perusahaan dimana terdapat keterkaitan antar subkriteria. Berdasarkan hasil pengolahan data dengan menggunakan model ANP diperoleh hasil sebagai berikut: alternatif toko daring yang dipilih mahasiswa Politeknik Ganesha sebagai toko daring terbaik adalah Shopee dengan bobot 3.80 sebagai prioritas utama, diikuti oleh Buka Lapak dengan bobot 3.73, prioritas ketiga adalah Lazada dengan bobot 2.47 .

b. Untuk menyempurnakan hasil penelitian ini, beberapa hal yang disarankan untuk dilakukan adalah: Perlu dilakukan pengujian usulan modei pemilihan toko daring terbaik pada contoh kasus yang berbeda sehingga dapat dilakukan perbaikan untuk menyempurnakan hasil pengambilan keputusannya dan Perlu adanya penelitian lanjutan guna merancang proses dan mekanisme penilaian beberapa kriteria keputusan secara lebih mendalam, terutama kriteria yang memiliki tingkat ketidakpastian.

\section{DAFTAR PUSTAKA}

[1] Fifin Sonata, "Analisis Studi Kelayakan Pelayanan E-Commerce Menggunakan Metode Analytical Hierarchy Process (ahp)”, Jurnal Komunikasi, Media dan Informatika, Vol. 7 No. 2 /Agustus 2018. 
[2] Kristophorus Kanaprio Ola dan Tri Joko Wahyu Adi, "Pemilihan kontraktor di proyek konstruksi pt. x dengan metode analytic network process", Prosiding Seminar Nasional Manajemen Teknologi XX Program Studi MMT-ITS, Surabaya 2014.

[3] Shanti Indri Hapsari dan Ahmad Rusdianyah, "aplikasi sistem pendukung keputusan berbasis spreadsheet untuk menganalisis biaya penyelenggaraan pendidikan di program mmt-its", Prosiding Seminar Nasional Manajemen Teknologi VIII Program Studi MMT-ITS, Surabaya 2008.

[4] Melwin Syafrizal, "Sistem pendukung keputusan (decision support system)", Jurnal DASI ISSN: 1411-3201 Vol. 11 no. 3 september 2010.

[5] Yuli Astuti, M. Suyanto, Kusrini, "Sistem pendukung keputusan untuk pemilihan perguruan tinggi komputer swasta", Jurnal DASI ISSN: 1411-3201 vol. 12 no. 1 maret 2011.

[6] Zulfa Fitri Ikatrinasari, Syamsul Maarif, Endang Gumbira Sa'id, Tajuddin Bantacut, Aris Munandar, "Model pemilihan kelembagaan agropolitan berbasis agroindustri dengan analytical network process", J. Tek. Ind. Pert. Vol. 19(3), 130-137.

[7] Iwan Vanany, "Aplikasi analytic network process (anp) pada perancangan sistem pengukuran kinerja (studi kasus pada pt. x)", Jurnal teknik industri vol. 5, no. 1, juni 2003: 50 - 62.

[8] Chandra Priyandika dan Mosses L. Singgih, "Pengambilan keputusan multi kriteria dalam pemilihan vendor Alat Pelindung Diri (APD) dengan pendekatan risk management dan analysis network process (anp)", Prosiding Seminar Nasional Manajemen Teknologi XIII Program Studi MMT-ITS, Surabaya 5 Pebruari 2011. 